УдК 637.5.05/07

\title{
THE INFLUENCE OF SLAUGHTER TECHNOLOGY ON THE FORMATION OF FUNCTIONAL INDICATORS OF MEAT
}

\author{
I. Strashynskyi, V. Pasichniy, O. Fursik \\ National University of Food Technologies
}

\begin{tabular}{|c|c|}
\hline Key words: & ABSTRACT \\
\hline $\begin{array}{l}\text { functional and } \\
\text { technological properties, } \\
\text { pork meat, } \\
\text { autolysis, } \\
\text { stunning, } \\
\text { bleeding }\end{array}$ & $\begin{array}{l}\text { The various methods of pre-slaughter aging of animals, chan- } \\
\text { ges in transportation conditions to the place of slaughter, methods } \\
\text { of stunning, etc. are used to reduce the amount of raw materials } \\
\text { with signs of deviation from the normal course of autolysis. At } \\
\text { present, there is no consensus on the advantages of this or that } \\
\text { immobilization method, especially in the case of electro-stunning }\end{array}$ \\
\hline $\begin{array}{l}\quad \text { Article history: } \\
\text { Received } 15.04 .2019 \\
\text { Received in revised form } \\
15.05 .2020 \\
\text { Accepted } 05.06 .2020\end{array}$ & $\begin{array}{l}\text { animal, the solution to this issue is important for the directed } \\
\text { influence on the quality of meat. An important issue is the study } \\
\text { of stress factors that arise with various parameters and methods } \\
\text { of immobilizing animals and affect on the physiological state of } \\
\text { the body and the quality of obtained meat. }\end{array}$ \\
\hline $\begin{array}{l}\text { Corresponding author: } \\
\text { sim2407@ukr.net }\end{array}$ & $\begin{array}{l}\text { In this article data of monitoring the quality indicators of pork } \\
\text { meat, which is obtained at LLC "Ternopol Meat Processing } \\
\text { Plant" are presented and the influence of stunning and bleeding } \\
\text { processes on its quality was studied. Determination of pH in- } \\
\text { dicator allowed us to establish that the use of vertical bleeding } \\
\text { will partially reduce the possibility of the manifestation of PSE } \\
\text { signs in pork meat, since the pH increases by } 0.13-0.19 \text { units } \\
\text { compared to horizontal bleeding. } \\
\text { Comparing the changes in the indicators of water-binding and } \\
\text { water-holding abilities with different stunning methods and the } \\
\text { same methods of bleeding, the best influence of the mechanical } \\
\text { method should be noted. This is evident from the functional and } \\
\text { technological indicators, since the indicators of water-binding } \\
\text { and water-holding abilities with the mechanical method of stun- } \\
\text { ning are higher by } 12.7-18 \% \text { (vertical bleeding) and by } 19.7- \\
22.4 \% \text { (horizontal bleeding) compared to the electric method for } \\
\text { raw materials } 24 \text { hours after slaughter. } \\
\text { It is established that in order to obtain raw materials with } \\
\text { higher functional and technological parameters it is advisable to } \\
\text { use a vertical method of bleeding in combination with mecha- } \\
\text { nical stunning at the enterprise. }\end{array}$ \\
\hline
\end{tabular}

DOI: $10.24263 / 2225-2916-2020-27-9$

(C) I. М. Страшинський, В. М. Пасічний, О. П. Фурсік, 2020 


\title{
ВПЛИВ ТЕХНОЛОГІЇ ЗАБОЮ НА ФОРМУВАННЯ ФУНКЦІОНАЛЬНИХ ПОКАЗНИКІВ М'ЯСА
}

\author{
І. М. Страшинський, канд. техн. наук \\ В. М. Пасічний, д-р техн. наук \\ О. П. Фурсік \\ Національний університет харчових технологій
}

У статті проведено моніторинг якісних показників м'яса свинини, яку отримують
на ТОВ «Тернопільський м'ясокомбінат», та вивчено вплив процесів оглушення і
знекровлення на ї̈ якість. Визначення показника рН дало змогу встановити, що
використання вертикального знекровлення частково зменшує можливість прояву
ознак РSЕ у м'ясі свинини. Порівнюючи зміни показників вологозв'язуючої та воло-
гоутримуючої здатностей при різних способах оглушення і однакових способах
знекровлення, слід відмітити ефрективніший вплив механічного способу. Показник
вологозв'язуючої здатності в середньому збільшується на 16, $2 \%$, вологоутри-
муючої-на 20,2\% порівняно з електричним оглушенням через 24 год після забою.
Встановлено, що для забезпечення отримання сировини з вищими фрункиіонально-
технологічними показниками на підприємстві доцільно використовувати верти-
кальний спосіб знекровлення у поєднанні з механічним оглушенням.

Ключові слова: функціонально-технологічні властивості, м'ясо свинини, автоліз, оглушення, знекровлення.

Постановка проблеми. На сьогодні питання цілеспрямованого використання сировини з урахуванням характеру автолітичних змін набуває особливого значення, оскільки суттєво зросла частка тварин, які надходять на переробку і в яких після забою в тканинах виявляються значні відхилення від нормального розвитку автолітичних процесів. Дані про кількість м'ясної сировини з нетрадиційними властивостями PSE (бліде, м'яке, водянисте) і DFD (темне, сухе, тверде) - неоднозначні. В окремих регіонах кількість яловичини DFD складає 28-35\%, свинини PSE 40-45\%, в країнах Свропи, США, Канаді і Австралії цей показник сягає 50\% [1]. Для зниження кількості PSE і DFD сировини використовують різні способи передзабійної витримки тварин, зміни умов транспортування до місця забою, способів оглушення тощо.

Однією з найбільш важливих технологічних операцій процесу переробки тварин $є$ оглушення. Оглушення впливає на ступінь знекровлення, i опосередковано на якість м'яса. Тому процес оглушення не слід розглядати лише з технічного боку. Для оглушення тварин на м'ясокомбінатах використовують електричні, механічні, хімічні способи $[2 ; 3]$.

На сьогодні відсутня єдина думка про переваги того чи іншого способу знерухомлення, особливо при електрооглушенні тварин, тому вирішення цього питання має важливе значення для спрямованого впливу на якість м'яса. Важливим питанням є вивчення стресових факторів, які виникають при різних параметрах і способах знерухомлення тварин і впливають на фізіологічний стан організму і якість отриманого м'яса. Встановлено, що в перші 24 год після забою тварини автолітичні зміни залежать від способу оглушення. Інтенсивний розпад глікогену протягом перших 12 год після забою відбувається в м'ясі тварин, оглушених електричним стру- 
мом, і дуже повільно відбувається в м'ясі тварин, оглушених міорелаксантами диполяризуючою дії (дітилином). У м'ясі тварин, оглушених електричним струмом, відбувається швидке розщеплення АТФ і розвиток посмертного задубіння [4].

Електрооглушення підвищує кров'яний тиск і спричинює довільне скорочення мускулатури тварин, яке нагадує судоми. Внаслідок цього нерідко у свиней спостерігаються крововиливи в туші, в легенях - у вигляді крапок, підвищення жорсткості м'яса і зниження його стійкості при зберіганні. Дослідження [5; 6] показали, що при електрооглушенні свиней у 6-9\% туш виявлено крапкоподібні крововиливи внаслідок значного підвищення кров' яного тиску і розривів капілярів. Вважають, що причиною таких крововиливів при електрооглушенні є збільшення в'язкості і зсідання крові. Крім того, є дані, що при електрооглушенні внаслідок збудження тварини вивільняється більше протромбіну, внаслідок чого настає більш інтенсивне зсідання крові, неповне знекровлення і погіршення товарного вигляду туші [7].

Для оглушення свиней використовують вуглекислий газ концентрацією 80 $85 \%$ протягом 75 с, параліч свиней продовжується $1-2$ хв. Задана концентрація $\mathrm{CO}_{2}$ підтримується автоматично, при цьому досягають швидкого і якісного знекровлення, кров в органах не накопичується, оскільки м'язи розслаблені, в них відсутні крововиливи.

На противагу послідовно роздільній організації забою при електрооглушенні, розробники систем газового оглушення зрештою запропонували практично ідеальний процес з точки зору безстресового впливу на тварин. По-перше, газові модулі припускають оглушення тварин невеликими партіями по 6-8 свиней: направляти тварин групою в прогін до воріт гондоли набагато легше. Автоматизовані системи напряму свиней виключають людський фактор: жодних електричних палиць. До переваг відноситься великий продуктивний потенціал цього методу оглушення, оскільки за один раз «присипається» кілька голів. Важливою перевагою оглушення $\mathrm{CO}_{2} \epsilon$ і та обставина, що вік і маса забійних тварин не має особливого значення: в гондолі можна легко комбінувати тварин - від свиноматок до поросят. Тривалість ефективного газового оглушення лежить у діапазоні від 45 секунд до 3 хвилин. На жаль, в оглушенні методом $\mathrm{CO}_{2} є$ і певні недоліки: тільки генетична схильність обраної породи свиней до якоїсь конкретної реакції на вуглекислий газ визначає можливість проведення оглушення газом, що в кожному окремому випадку визначається дослідним шляхом [4].

Знекровлення також є одним із найважливіших технологічних процесів, оскільки від ступеня видалення крові значною мірою залежить товарна та санітарна якість м'яса і стійкість його при зберіганні. Один із головних показників товарного виду туш — колір м'яса. В разі неповного знекровлення м'ясо на розрізі темніє, поверхневі малі судини переповнені кров'ю. При неправильному проведенні процесу знекровлення грудна порожнина заповнюється кров'ю, яка просочує м'язову та жирову тканини лівої і передньої частини. Зачистка цих ділянок приводить до втрати маси туші і зниження іiі товарного виду. Крім того, туша знекровлюється гірше, а накопичена в грудній порожнині кров погіршує якість субпродуктів.

Ступінь знекровлення туш залежить від таких факторів: технології проведення забою, фізіологічного стану тварини перед забоєм, часу розтину судин після оглушення тварин при знекровленні. Погане знекровлення при дотриманні технології забою - показник того, що у тварини перед забоєм були фізіологічні відхилення. Знекровлення туш погіршується при передзабійних стресах і втомі тварин, оскільки ці стани посилюють приток крові до м’язів, внаслідок чого зменшується кількість 
виділення крові. Для більш повного знекровлення і дотримання санітарії використовують установки для збирання харчової крові під вакуумом, що дає змогу збільшити вихід крові на харчові цілі на 5 \%, значно покращує якість м’яса [8-10]. У технології існує два способи проведення процесу знекровлення - вертикальне і горизонтальне. Вибір одного з них безпосередньо вплине на якість отриманого м'яса.

Для отримання м'ясної сировини високої якості із відсутністю відхилень у ході автолітичних процесів на виробництві необхідно правильно підібрати і контролювати технологічні процеси обробки, зокрема оглушення і знекровлення.

Мета дослідження полягає у проведенні моніторингу якісних показників м'яса свинини, яку отримують на ТОВ «Тернопільський м’ясокомбінат» та вивченні впливу технологічних факторів на ії якість.

Матеріали і методи. Об'єкт дослідження: технологія первинної переробки свиней. Предмет дослідження: м'ясо свинини, отримане після забою тварин на ТОВ «Тернопільський м'ясокомбінат».

Для характеристики якості м'яса після забою залежно від обраних технологічних процесів оглушення та знекровлення провели дослідження показників $\mathrm{pH}$, вологозв'язуючої (В33) та вологоутримуючої здатності (ВУЗ) для дослідних зразків м'яса свинини.

Визначення концентрації іонів водню проводили на pH-метрі testo 205 [11].

Межі визначення показника $\mathrm{pH}$ від 0 до 14 одиниць, при температурі в діапазоні $0-60^{\circ} \mathrm{C}$; крок - $0,01 \mathrm{pH}$ одиниць, $0,1^{\circ} \mathrm{C}$; похибка - $\pm 0,02 \mathrm{pH}, \pm 0,4^{\circ} \mathrm{C}$.

Метод визначення вологозв'язуючої здатності (В33) грунтується на виділенні води 3300 мг наважки при 10-хвилинному пресуванні тягарем масою 1 кг. Визначення проводять за розміром плями, що залишається на фільтрувальному папері після сорбції ним виділеної вологи, окреслюючи олівцем контур плями спресованого м'яса.

Розмір вологої плями (зовнішньої) вираховують по різниці між загальною площею плями і площею плями, утвореною м'ясом (продуктом) [12].

Вміст зв' язаної вологи розраховують за формулами:

$$
\mathrm{B} 33=(\mathrm{A}-8,4 \mathrm{~B}) \cdot 100 / \mathrm{A},
$$

В33 - вміст зв'язаної вологи, \% до загальної вологи;

A - загальний вміст вологи в наважці, мг;

Б - площа вологої плями, $\mathrm{cm}^{2}$.

Вологоутримуючу здатність (ВУЗ) визначали за кількісним вмістом води, що утримується дослідним зразком після термічної обробки [13]:

$$
\mathrm{BУ} 3=\mathrm{B}-\mathrm{BB} 3 .
$$

Вологовиділяючу здатність (ВВ3) розраховують за формулою:

$$
\mathrm{BB} 3=\mathrm{a} \cdot \mathrm{n} \cdot \mathrm{m}^{-1} \cdot 100 \%
$$

де В - загальна масова частка вологи в наважці, \%; а — ціна поділки жироміра; $\mathrm{n}$ - число поділок на шкалі жироміра; $\mathrm{m}$ - маса наважки, г.

Визначення показника виходу м'яса при термічній обробці здійснювали шляхом варіння на водяній бані протягом 60 хвилин при $80^{\circ} \mathrm{C}$. Після закінчення заданого часу зразки виймають з бульйону пінцетом, дають стекти бульйону і використовують для визначення виходу м'яса [14].

Показник виходу розраховували за формулою:

Вихід $=\mathrm{m}_{\Pi} / \mathrm{m}_{д} \cdot 100, \%$, 
де $\mathrm{m}_{п}$ - маса м'яса після термічної обробки, г; $\mathrm{m}_{д}$ - маса м'яса до термічної обробки, г.

Результати дослідження. На ТОВ «Тернопільський м'ясокомбінат» застосовують горизонтальне знекровлення. Проте згідно з літературними даними вертикальне знекровлення має ряд переваг перед горизонтальним. По-перше, при вертикальному знекровленні відбувається більший вихід крові, по-друге, туша краще знекровлюється.

У зв'язку з цим було досліджено фактори, які впливають на якість м'яса, такі як способи оглушення і знекровлення. Для дослідження було взято по 20 туш свиней. Отримано дані впливу способів оглушення і знекровлення тварин на рН (рис. 1-5), показники В33, ВУЗ та вихід при варінні. Дослідження м'язової тканини проводили через 1 год та 24 год після забою.

Визначення показника рН дало змогу встановити, що як при електричному, так і при механічному оглушенні раціональніше використовувати вертикальне знекровлення. Значення $\mathrm{pH}$ при електричному оглушенні і вертикальному знекровленні на 0,19 одиниць вище порівняно із горизонтальним через 24 год після забою і становить 5,68. При механічному оглушенні і вертикальному знекровленні показник $\mathrm{pH}$ збільшується на 0,13 одиниць порівняно 3 горизонтальним через 24 год після забою і становить 5,8. Це дало змогу встановити, що використання вертикального знекровлення частково зменшує можливість прояву ознак PSE в м'ясі свинини. Порівнюючи значення $\mathrm{pH}$ для різних способів оглушення при вертикальному знекровленні, доцільно відмітити механічний спосіб, оскільки $\mathrm{pH}$ збільшується на 0,12 одиниць порівняно з електричним через 24 год після забою.

До показників, які характеризують якість м'яса після забою і дають змогу встановити відхилення від нормального перебігу процесу автолізу належать показники В33 і ВУЗ. На рис. 1-4 представлені дані зміни показників В3З і ВУЗ залежно від способу знекровлення і способу оглушення через 1 год і 24 год після забою.

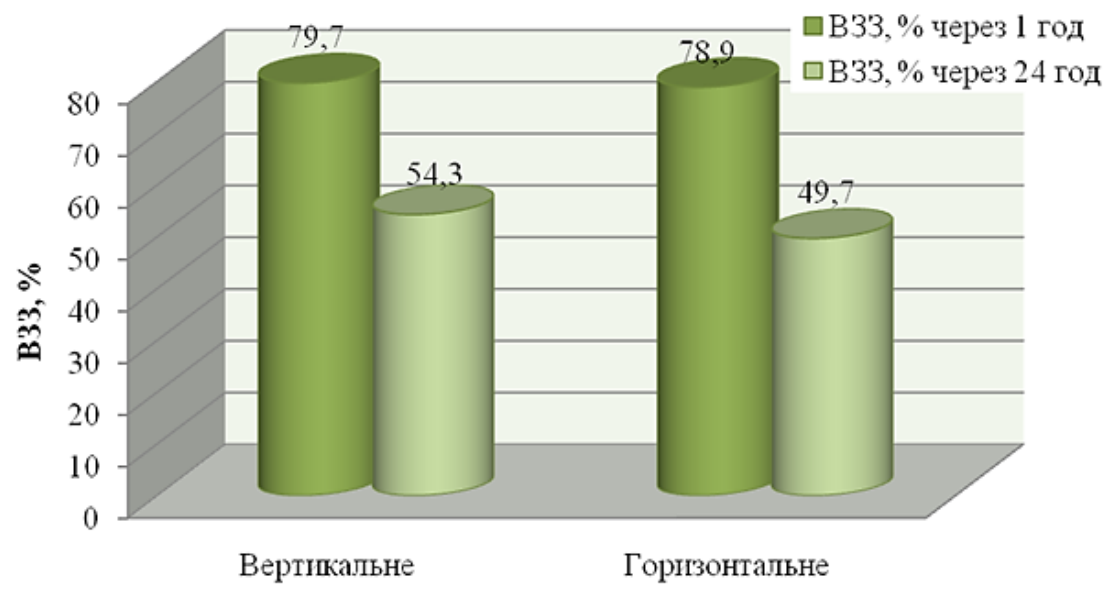

Спосіб знекровлення

Рис. 1. Вплив вертикального і горизонтального знекровлення при електричному оглушенні на показник В33 через 1 год та 24 год після забою 
Згідно $з$ діаграмою (рис. 1), показник В33 вищий на 4,6\% при вертикальному знекровленні порівняно з горизонтальним через 24 год після забою. Що ж стосується показника В33 через 1 год після забою, то отримані значення знаходяться в межах похибки, що свідчать про незначний вплив способу знекровлення на показник В33 для парного м’яса.

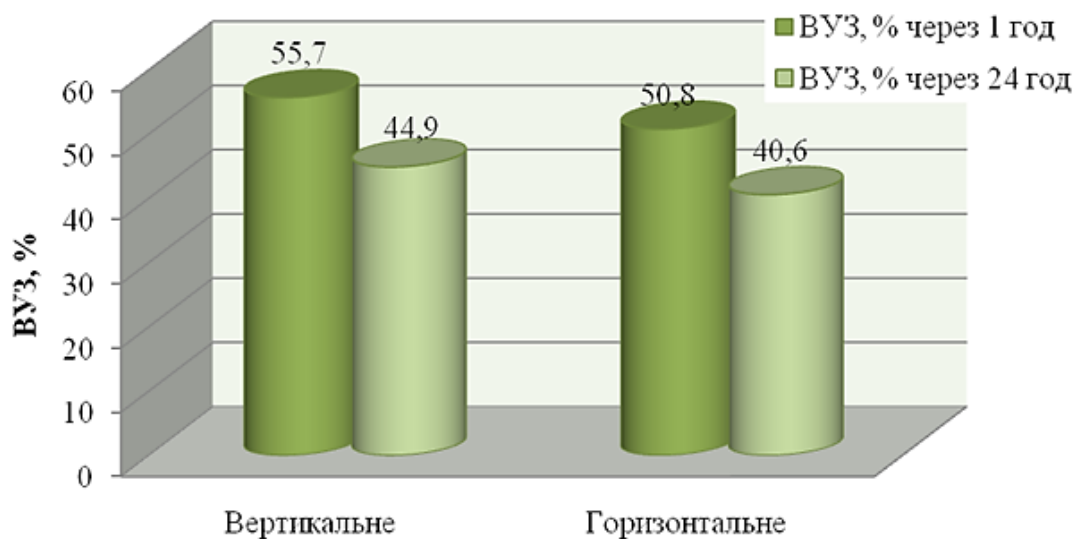

Спосіб знекровлення

Рис. 2. Вплив вертикального і горизонтального знекровлення при електричному оглушенні на показник ВУЗ через 1 год та 24 год після забою

Аналогічна тенденція спостерігається у зміні показника ВУЗ для м'яса через 1 год і 24 год після забою (рис. 2). При однаковому способі оглушення кращою здатністю утримувати вологу в структурі характеризується м'ясна сировина, отримана при застосуванні вертикального способу знекровлення (показник ВУЗ вищий на 9,6\% через 1 год після забою і 10,6\% через 24 год після забою) порівняно iз горизонтальним. Отримані дані обумовленні кращим ступенем знекровлення м'ясної туші, що позначається на перебігу процесів автолізу i, у свою чергу, формує якісні характеристики на різних етапах процесу.

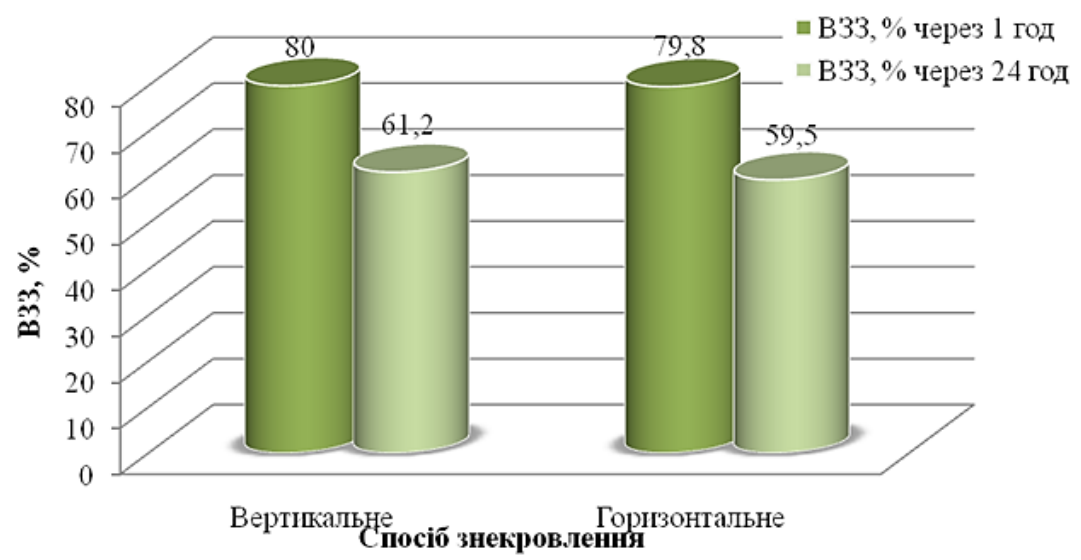

Рис. 3. Вплив вертикального і горизонтального знекровлення при механічному оглушенні на В33 через 1 год та 24 год після забою 
3 діаграми (рис. 2) видно, що показник В33 вищий на 1,7\% при вертикальному знекровленні порівняно 3 горизонтальним через 24 год після забою. Що ж стосується показника В33 через 1 год після, то отриманні значення знаходяться на однаковому рівні, що свідчать про незначний вплив способу знекровлення на показник В3З для парного м'яса.

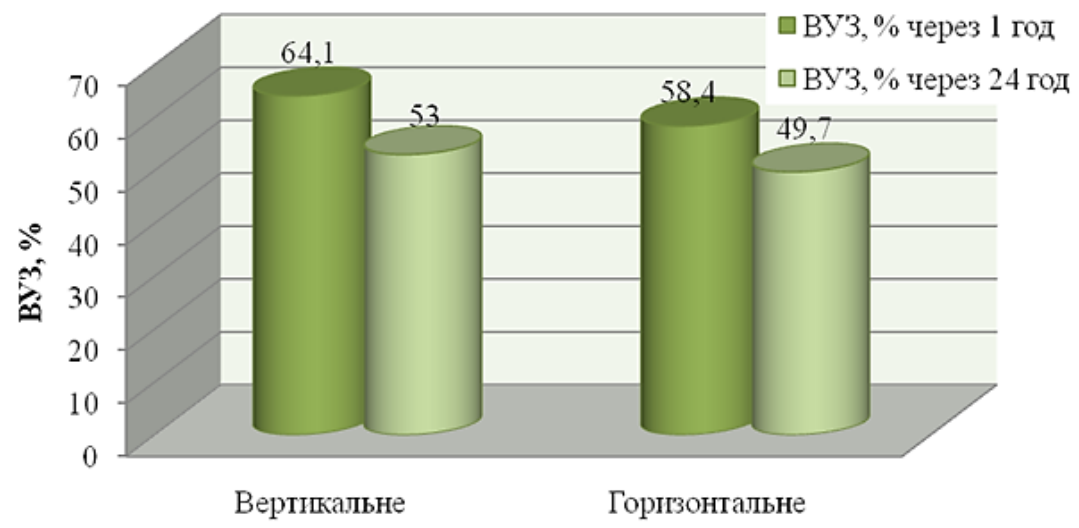

Спосіб знекровлення

Рис. 4. Вплив вертикального і горизонтального знекровлення при механічному оглушенні на ВУЗ через 1 год та 24 год після забою

Аналогічно попереднім даним при однаковому способі оглушення кращою здатністю утримувати вологу в структурі характеризується м'ясна сировина, отримана при застосуванні вертикального способу знекровлення (показник ВУЗ вищий на 9,7\% через 1 год після забою і 6,6\% через 24 год після забою) порівняно із горизонтальним.

Порівнюючи дані зміни показників В3З і ВУЗ при різних способах оглушення і однакових знекровлення, слід відмітити позитивний вплив механічного способу. Це видно із функціонально-технологічних показників. Так, показник В3З при механічному способі оглушення вищий на $12,7 \%$ (вертикальне знекровлення) та на $19,7 \%$ (горизонтальне знекровлення) порівняно 3 електричним способом для сировини через 24 год після забою. Що ж стосується цього показника для м'яса через 1 год після забою, то він не значно змінився залежно від способу оглушення (при однаковому знекровленні). Показник ВУЗ при механічному способі оглушення вищий на $18 \%$ (вертикальне знекровлення) і на 22,4\% (горизонтальне знекровлення) для сировини через 24 год після забою та на $15,1 \%$ (вертикальне знекровлення) і на 15\% (горизонтальне знекровлення) для сировини через 1 год після забою порівняно з електричним способом. Отримані дані дають змогу встановити, що для забезпечення отримання сировини із вищими функціональнотехнологічними показниками доцільно на підприємстві використовувати вертикальний спосіб знекровлення у поєднанні з механічним оглушенням.

Залежно від здатності м'яса утримувати вологу в своїй структурі змінюються показники виходу м'яса після варіння, що безпосередньо вплине на втрати при виробництві м'ясної продукції. На рис. 5 графічно наведені дані зміни виходу м'яса при варінні залежно від способів оглушення і знекровлення тварини при забої. 


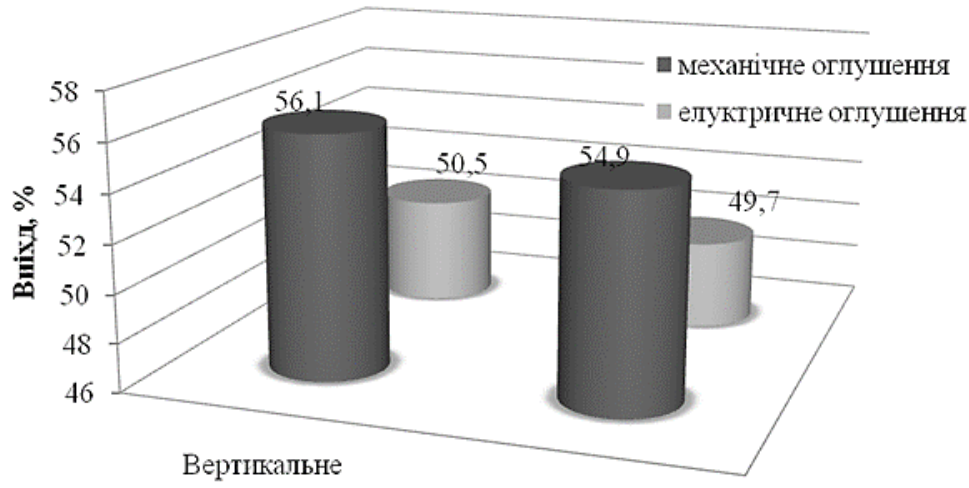

Горізонтальне

Спосіб знекровлення

\section{Рис. 5. Вплив вертикального і горизонтального знекровлення при механічному та електричному оглушенні на вихід при варінні}

При механічному оглушенні і вертикальному знекровленні вихід при варінні більший на $0,8 \%$, ніж при механічному оглушенні та горизонтальному знекровленні. За рахунок вертикального знекровлення при електричному оглушенні вихід при варінні збільшується на 2,2\%, ніж при горизонтальному знекровленні.

Отримані дані підтверджують переваги механічного способу оглушення в поєднанні з вертикальним знекровлення. Ці результати пов'язані з тим, що при механічному оглушенні вдається уникнути переломів кісток скелета і крововиливів у тканини і внутрішні органи. У результаті цього якість м'яса поліпшується порівняно 3 м'ясом, отриманим від тварин, що оглушені електричним струмом. Проте механічний процес оглушення є трудомістким, потребує високої кваліфікації працівників, небезпечний та в основному використовується на підприємствах невеликої потужності. Спираючись на літературний огляд та поступове збільшення продуктивності цеху забою свиней на ТОВ «Тернопільський м'ясокомбінат» доцільним є встановлення обладнання для газового оглушення. Адже він поєднує в собі переваги механічного і електричного способів і це забезпечить, поряд із відсутністю переломів кісток і крововиливів у м'язову тканину, порівняно нижчу трудомісткість i складність процесу та високі показники знекровлення і якості отриманої сировини.

Висновок. Підсумовуючи отримані результати досліджень впливу технологічних факторів на якість м'яса робимо висновок, що при механічному оглушенні і вертикальному знекровленні збільшуються показники рН в середньому на 0,15 одиниць, В33 - в середньому на 16,2\%, ВУЗ - на 20,2\% та зменшуються втрати при варінні в середньому на 10,8\% порівняно з електричним оглушенням. Отже, для підвищення функціонально-технологічних показників краще використовувати механічне оглушення та вертикальне знекровлення.

\section{ЛІТЕРАТУРА}

1. Бірта Г. О. Товарознавчі аспекти м’яса свинини / Г. О. Бірта, Ю. Г. Бургу, Л. В. Флока // Збірник наукових праць Подільського державного аграрного університету. —2012. — №20. C. 20-23.

2. Яремчук В. Анализ рисков при убое и переработке скота / В. П. Яремчук, В. И. Родин // Мясные технологии. — 2013. - № 11. - С. 24-28. 
3. Зимин М. Убой и переработка: от теории к практике / М. И. Зимин // Мясные технологии. - 2011. - № 4. - С. 34-35.

4. Carlin K. R. M. Effect of oxidation, $\mathrm{pH}$ and ionic strength on calpastatin inhibition ofl- andmcalpain / K. R. M. Carlin, E. Huff-Lonergan, L. J. Rowe, S. M. Lonergan // Journal of Animal Science. 2006. — № 84. — P. 925-937.

5. Barbut S. Progress in reducing the pale, soft and exudative (PSE) problem in pork and poultry meat / S. Barbut, A. A. Sosnicki, S. M. Lonergan, T. Knapp, D. C. Ciobanu, L. J. Gatcliffe, E. HuffLonergan, E. W. Wilson // Meat Science. - 2008. — №79. - P. 46-63.

6. Bidner B. Effect of ultimate $\mathrm{pH}$ on the quality characteristics of pork / B. Bidner, M. Ellis, M. S. Brewer, D. Campion, E. R. Wilson, F. K. McKeith // Journal of Muscle Foods. - 2004. №15. - - P. 139-154.

7. Ремізова Ю. О. Вади м'яса свинини за дії прижиттєвого технологічного температурного стресу / Ю. О. Ремізова // Наукові доповіді Національного університету біоресурсів і природокористування України. — 2016. — №4.

8. Страшинський І. М. Якість свинини, що переробляє ТОВ «Тернопільський м’ясокомбінат» / I. М. Страшинський, О. П. Фурсік, Р. О. Ришканич та ін. // Прогресивні техніка та технології харчових виробництв ресторанного господарства і торгівлі: зб. наук. пр. - Харків: ХДУХТ, 2019. - Вип. 1 (29). - С. 199 - 214.

9. Штибинг А. Факторы, влияющие на сенсорику свежего мяса / А. Штибинг, М. Упманн, Б. Шмит, Г. Тумель // Мясные технологии. — 2012. — №12. — С. 42-44.

10. Фейнер Г. Мясные продукты. Научные основы, технологии, практические рекомендации / Г. Фейнер. - Пер. с англ. Н. В. Магды, науч. ред. проф., чл.-кор. Международной академии информатизации при ООН В. Г. Поселков, к. т.н. Т. И. Проселкова. - СПб: Профессия, 2010. - 720 с.

11. ДСТУ ISO 2917:2001 М'ясо та м'ясні продукти. Метод визначення pH.

12. Жаринов А. И. Формы связи влаги в мясе и мясных продуктах / А. И. Жаринов, Н. А. Соколова // Вестник. Аромарос-М. — 2004. — №4. - С. 37-47.

13. Антипова Л. В. Методы исследования мяса и мясных продуктов / Л. В. Антипова, И. А. Глотова, И. А. Рогов - М.: Колос, 2001. - 570с.

14. Кишенько I. I. Технологія М'яса і М'ясопродуктів / I. І. Кишенько, В. М. Старчова, Г. І. Гончаров // Практикум: навч. посіб. - НУХТ: Київ. - 2010. - 367с.

\title{
ВЛИЯНИЕ ТЕХНОЛОГИИ УБОЯ НА ФОРМИРОВАНИЕ ФУНКЦИОНАЛЬНЫХ ПОКАЗАТЕЛЕЙ МЯСА
}

\author{
И. М. Страшинский, В. Н. Пасичный, О. П. Фурсик \\ Национальный университет пищевых технологий
}

\begin{abstract}
В статье представлены данные мониторинга качественных показателей мяса свинины, которую получают на ООО «Тернопольский мясокомбинат», и изучено влияние процессов оглушения и обескровливания на ее качество. Определение показателя $\mathrm{pH}$ позволило установить, что использование вертикального обескровливания позволит частично уменьшить возможность проявления признаков PSE в мясе свинины. Сравнивая изменения показателей влагосвязывающей и влагоудерживающей способностей при различных способах оглущения и одинаковых способах обескровливания следует отметить лучшее влияние механического способа. Установлено, что для получения сырья с высоким функционально-технологическими показателям, на предприятии иелесообразно использовать вертикальный способ обескровливания в сочетании с механическим оглушением.
\end{abstract}

Ключевые слова: функционально-технологические свойства, мясо свинины, автолиз, оглушение, обескровливание. 